\title{
Yeni Ekonomik Coğrafya Yaklaşımı Çerçevesinde İşgücünün Hareketliliği: Avrupa
}

\section{Birliği Uygulaması}

\section{Elif Tunalı Çalışkan ${ }^{1}$, A. Ayşen Kaya²}

İktisat teorilerinde mekansal etkileri gündeme getiren ve coğrafyanın uluslararası ticaretteki rolünü vurgulayan Ekonomik Coğrafya Yaklaşımı'nın temel varsayımlarından biri de işgücünün bölgeler içinde ve arasında hareketli olmasıdır. İşgücünün hareketliliği; ülkenin nüfusunu, işgücüne katılım oranını ve işgücünün niteliğini etkileyerek üretim yapısını, ekonomik gelişme yönünü ve düzeyini belirlemektedir.

Yeni Ekonomik Coğrafya Yaklaşımında, işgücünün yerleşim yeri tercihleri ülkeler arasındaki ücret farklılıklarına dayandırılmaktadır. Ancak, yüksek ücret tek başına işgücünün ülkeye çekilmesi için yeterli değildir. Ücretlerin yanı sıra ülkenin sosyo-kültürel yapısı da özellikle ücretlerin birbirine yakın olduğu ülkeler arasında seçim yaparken etkili olmaktadır. $\mathrm{Bu}$ çerçevede çalışmanın amacı; işgücünün yerleşim yeri tercihlerini etkileyen faktörleri analiz edebilmek ve bu sayede literatüre katkıda bulunabilmektir. Çalışmada, Avrupa Birliği ülkeleri arasında işgücünün hareketliliğini belirleyen unsurlar Yeni Ekonomik Coğrafya çerçevesinde En Küçük Kareler (EKK) ve Genelleştirilmiş Momentler Yöntemi (GMM) kullanılarak panel veri analizi ile incelenmiştir. $\mathrm{Bu}$ sayede, üretim yapısının şekillenmesinde önemli rol alan işgücünün hangi ülkeleri, neden daha fazla tercih ettikleri ortaya koyulmaya çalışılmıştır.

Anahtar Kelimeler: Yeni Ekonomik Coğrafya, işgücünün hareketliliği

* Çalışmanın ilk versiyonu EconAnadolu 2013 Kongresinde sunulmuştur. 


\section{Labor Mobility in the Light of New Economic Geography: The Case of European Union}

\section{Abstract}

One of the fundamental assumptions of New Economic Geography Approach which brought up spatial effects in economic theories and emphised the role of geography in international trade is labor mobility within and between countries. Labor mobility determines the structure of production, the direction and the level of economic development by affecting the local population, the participation rate of labor force and the labor quality.

In New Economic Geography Theory labors' location choices is determined by wage differences. But wages by itself is not enough to attract labor to the country. Aside from high wages, the socio-cultural structure of the country has an important role especially in choosing between locations where wages are close to each other. Therefore, the purpose of this paper is to analyze the factors that affect the location choices of the labor force. This paper is to investigate the labor mobility among EU15 with panel data analysis by using OLS and GMM methodology. Thus, this paper tries to explain why/how mobile labor force prefer one country to another.

Key Words: New Economic Geography, Labor Mobility 


\section{Ege Strategic Research Journal}

\section{GİRİș}

Son yıllarda talep yapısında görülen değişimler ve küresel rekabetin şiddetlenmesi ile birlikte iktisadi faaliyetlerin bölgeler/ülkeler arasında hızla yer değiştirdiği ve bazı bölgelerde/ülkelerde yığınlaştığı görülmüştür. Geleneksel iktisat teorileri ortaya çıkan bu mekansal değişimi açıklamada yetersiz kalırken, 1990’lı yıllarda Paul Krugman'ın öncülüğünde bir grup iktisatçı yaşanan değişimi açıklamada coğrafyanın önemini gündeme getirmişlerdir. Krugman (1991) tarafından oluşturulan Yeni Ekonomik Coğrafya modeli Fujita (1993), Venables (1996) ve Puga (1999) gibi iktisatçılar tarafından daha da geliştirilmiştir. Bu yaklaşımın temel varsayımları, ölçeğe göre artan getiriler, eksik rekabet piyasaları ve üretim faktörlerin hareketliliğidir. Böylelikle ekonomik düzende yaşanan değişim, mekansal etkileri de göz önünde bulundurarak ulaşım maliyetleri ve faktörlerin hareketliliği aracılığıyla dinamik denge modelleri ile açıklanır hale getirilmiştir.

Yeni Ekonomik Coğrafya Yaklaşımı'nın en önemli özelliklerinden biri işgücünün ülkeler içinde ve arasında hareketli olmasıdır (Fujita ve Krugman, 2004: 147). İşgücünün hareketliliği, ülkelerin nüfusunu, işgücüne katılım oranını ve işgücünün niteliğini etkileyerek ülkenin üretim yapısını, ekonomik gelişme yönünü ve düzeyini belirlemektedir. Bu yaklaşıma göre işgücünün yerleşim yeri kararlarının belirleyicisi ülkeler arasındaki ücret farklılıklarıdır (Brakman vd; 2002: 11). Ancak işgücü hareketliliğinin nedenini sadece ekonomik perspektifte tanımlamak yeterli gelmemektedir. Özellikle son on yıldır ekonomik coğrafya alanında etkin olan ve evrimci iktisadın temel görüşlerini ekonomik coğrafya kapsamında inceleyen Evrimci Ekonomik Coğrafya Yaklaşımı, yerleşim yeri kararlarında toplumun sosyo-kültürel yapısının ve ülkenin ekonomik yapısında görülen patika bağımlılığının da etkin olduğunu belirtmektedir (Boschma ve Frenken, 2006: 277). 
$\mathrm{Bu}$ kapsamda çalışmanın amacı; işgücünün yerleşim yeri tercihlerini etkileyen faktörleri analiz edebilmektir. Bu sayede, ülkelerin üretim yapısının şekillenmesinde önemli rol alan işgücünün neden bazı ülkeleri daha fazla tercih ettiği ortaya koyulmaya çalışılmıştır. Ekonomik coğrafya literatürü incelendiğinde, işgücünün yerleşim yeri kararlarına yönelik sınırlı sayıda ampirik çalışma bulunduğu ve bu çalışmaların da sadece ücret farklılıklarını yani ekonomik tercihleri dikkate aldığı görülmüştür. Ancak yaklaşım böyle bir durumda ücret farklılıkları birbirlerine yakın olan ülkeler arasında nasıl seçim yapıldığı konusuna açıklık getirememektedir. Bu durum göz önüne alınarak, çalışmada işgücünün yerleşim yeri seçim kararlarında ekonomik etkiler dışında sosyo-kültürel faktörlerin etkili olup olmadığı araştırılarak literatüre katkıda bulunulmaya çalışılmıştır. Çalışmanın ilk bölümünde, Yeni Ekonomik Coğrafya Yaklaşımı'nın gelişimi, temel özellikleri ve bu yaklaşım çerçevesinde işgücünün hareketliliği incelenmiştir. İkinci bölümde ise, Evrimci Ekonomik Coğrafya Yaklaşımı ile Yeni Ekonomik Coğrafya Yaklaşımı arasındaki farklar ve benzerlikler ortaya koyularak bu çerçevede işgücünün hareketliliğinin nedenleri açıklanmıştır. Son bölümünde, literatür özetine yer verilmiş ve Avrupa Birliği’nin 15 ülkesi için işgücünün yerleşim yeri tercih nedenleri 2003-2010 yıl aralığında analiz edilmiştir.

\section{Yeni Ekonomik Coğrafya Yaklaşımı ve İşgücünün Hareketliliği}

Ekonomik Coğrafya modelleri genel olarak mekansal etkileri göz önünde bulundurarak ekonomik, sosyal, kültürel ve beşeri boyutlarda yığın ekonomilerinin oluşumunu incelemektedir. Bu kapsamda ortaya çıkan Yeni Ekonomik Coğrafya Yaklaşımı geleneksel iktisat teorisyenlerinin uzun y1llar boyunca gereken önemi vermedikleri mesafe ve ulaşım maliyetlerini analizlerine konu ederek, iktisadi faaliyetlerin coğrafi dağılımını ve bu dağılımı etkileyen faktörleri açıklamaya çalışmaktadır (Schmutzeler, 1999: 355). Bu yaklaşım iktisadi faaliyetlerin mekansal dağılımında hem piyasa etkilerini hem de makro 
Ege Strategic Research Journal

ekonomik gelişmeleri dikkate aldığı için geleneksel iktisat teorilerinde yer alan statik denge yerini dinamik dengeye birakmaktadır.

Yeni Ekonomik Coğrafya Yaklaşımı'nın amacı hem iktisadi faaliyetleri bir arada tutarak yığın ekonomileri yaratan merkezcil kuvvetlerin hem de iktisadi faaliyetlerin dağılmasına neden olan merkezkaç kuvvetlerin aynı anda tartışılmasını sağlamaktır (Fujita ve Krugman, 2004: 141). Merkezcil ve merkezkaç kuvvetlerin birbirleri ile olan ilişkilerini açıklamak iktisadi faaliyetlerin coğrafi dağılımını etkilen unsurları ortaya koymak için gerekmektedir. Tablo 1 Merkezcil ve Merkezkaç Kuvvetleri göstermektedir.

Tablo 1:

\begin{tabular}{lc}
\hline YIĞINLAŞMAYI ETKÍLEYEN FAKTÖRLER \\
\hline Merkezcil Kuvvetler & Merkezkaç Kuvvetleri \\
Piyasa Büyüklü̆ğ̈ Etkileri & Mobil Olmayan Faktörler \\
Yoğun İsü̈cü Piyasaları & Arazi/toprak Kiraları \\
Saf Dışsal Ekonomiler & Saf Negatif Dışsal Ekonomiler
\end{tabular}

Kaynak: Krugman, 1998: 8

Merkezcil Kuvvetler; piyasa büyüklüğü etkileri, işgücü piyasasının yoğunlaşması ve saf dışsal ekonomileri içermektedir. Piyasa büyüklüğü etkileri; firmaların ülkeye yerleşim kararları sonucunda ortaya çıkan ileri ve geri bağlantı etkilerinin güçlü olması durumunda, diğer firmalarında bu ülkeye çekilmesini sağlayarak endüstriyel yığınlaşmaya neden olacağını ifade etmektedir (Venables, 1998: 4). Yoğun işgücü piyasaları işçi-işveren eşleşmesinin her iki taraf açısından da kolay olması anlamına gelmektedir. Bu etki hem firmaların hem de işgücünün ülkeye çekilerek yığınlaşma sürecinin hız kazanmasını sağlamaktadır. Saf dışsal ekonomiler ise bilgi yayılımı sayesinde yine yı̆̆ın ekonomilerin ortaya çıkmasına neden olmaktadır (Krugman, 1998:3). 
Merkezkaç kuvvetler; mobil olmayan faktörler, arazi kiraları ve saf dışsal ekonomilerden oluşmaktadır. Toprak ve doğal kaynaklar gibi mobil olmayan faktörler üretimin yoğunlaşmasına engel olmaktadır. Yığın ekonomilerinin görüldüğü ülkelerde ise, bir süre sonra arazi ve konut maliyetleri artacağı için bu maliyetler nedeniyle oluşabilecek daha etkin yığınlaşmalar görülememektedir. Ayrıca, ülkedeki nüfusun artması, ülkenin kalabalıklaşmasına ve trafik tıkanıklıklarına neden olurken, yığınlaşma sonucunda ülkedeki firma sayısının artması ücretlerin yükselmesine neden olarak yığınlaşmayı önleyici saf dışsal ekonomiler yaratmaktadır.

Tablo 2:

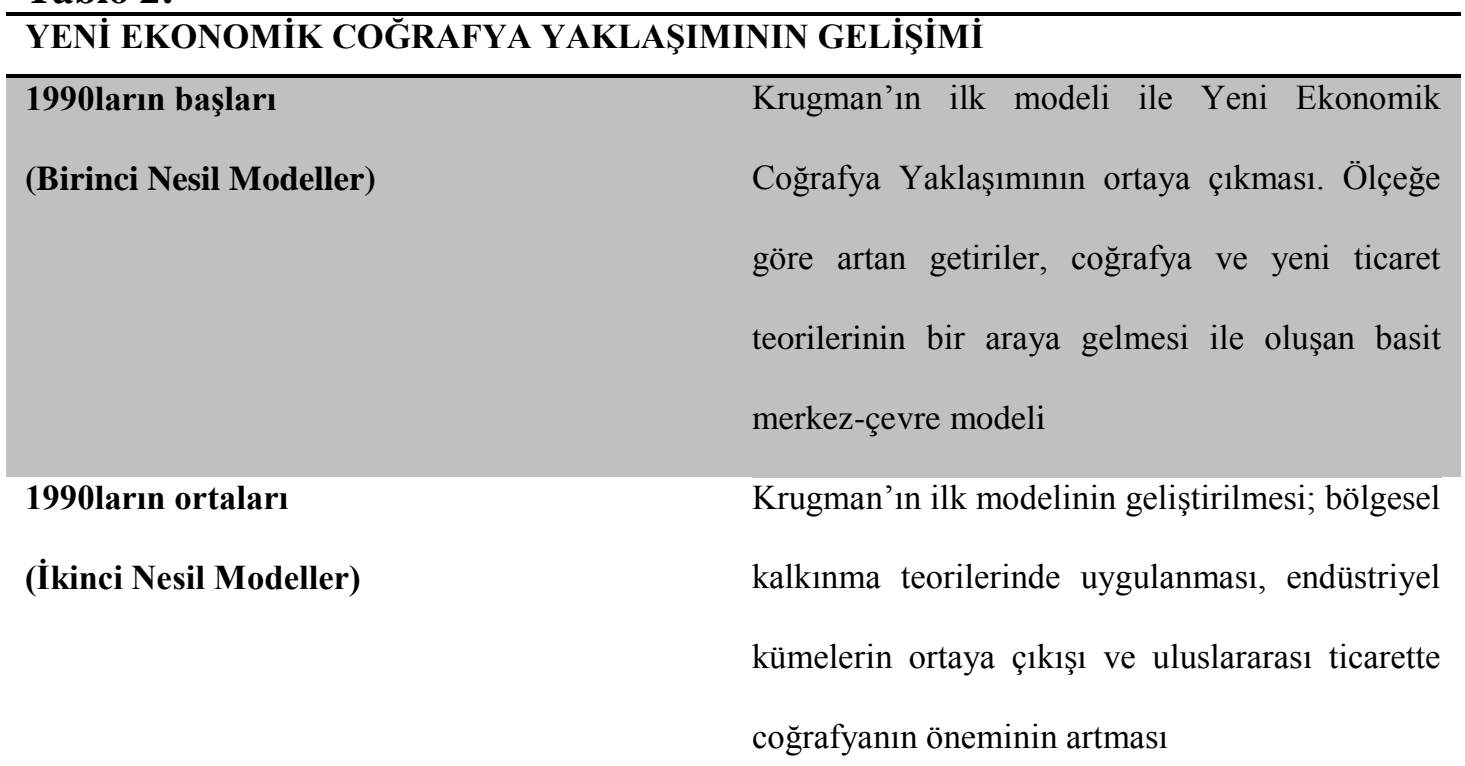

2000li yıllar

(Üçüncü Nesil Modeller)
Teknolojik gelişmelerin ve bilgi dışsallıklarının ve yayılımının modele eklenmesi, ampirik analizlerin başlaması ve politika önerilerinin geliştirilmesi:

Kaynak: Martin ,2010: 59 
Ege Strategic Research Journal

Tablo 2 Yeni Ekonomik Coğrafya Yaklaşımının gelişimini göstermektedir. Bu yaklaşımın temellerini oluşturan ilk çalışma Krugman (1991) tarafından yapılmıştır. Krugman'ın bu çalışmasının en bilinen özelliği geleneksel Arrow- Debrau tipi dengenin yerine Dixit ve Stiglitz'in (1977) ölçeğe göre artan getirileri ve monopolcü rekabeti bölgesel analizlere dahil ettikleri modelini kullanmasıdır. Krugman, iki bölge ve iki sektörlü modeli ile Yeni Ekonomik Coğrafya Yaklaşımı'nın varsayımlarını ve temel özelliklerini açıklayarak bölgesel iktisat teorinde coğrafyanın etkisini içselleştirerek yeni bir yön kazandırmıştır. Bu çalışmanın ardından literatüre önemli katkıları olan pek çok çalışma yapılmış ve Yeni Ekonomik Coğrafya modelinin temel özellikleri ve varsayımları günümüz iktisadi koşullarını açıklayabilecek biçimde şekillenmiştir.

Günümüzde Yeni Ekonomik Coğrafya modellerinin kilit unsurları ürün farklılaştırmasını modelleştiren çeşitlilik varsayımı, ölçeğe göre artan getiri ve ulaşım maliyetlerinden oluşmaktadır (Redding, 2009:2). Bu kilit unsular faktör mobilitesi ile bir araya geldiğinde yığınlaşmaların ve kümelenmelerin oluşumunu destekleyici nitelikte etki yaratmaktadır (Arias ve Grajeda, 2009:2). Dolayısıyla bu yaklaşım incelenirken üzerinde durulması gereken temel kavramlar; çeşitlilik, ölçeğe göre artan getiriler, eksik rekabet piyasaları, endüstri-içi ticaret, faktör mobilitesi ve ulaşım maliyetleri olarak karşımıza çıkmaktadır (Fujita ve Krugman, 2004:147). Bu özellikleri bir araya getirmesi ile Yeni Ekonomik Coğrafya Yaklaşımı diğer yaklaşımlardan farklılaşmaktadır. Tablo 3 yaklaşımın temel özelliklerini özetlemektedir. 
Tablo 3:

\begin{tabular}{l|l}
\hline \multicolumn{1}{|c}{ TABLO 3: YENİ EKONOMIK COĞRAFYA YAKLAŞIMININ TEMEL ÖZELLİKLERİ } \\
\hline Çeşitlilik & Ürün Farklılaşması \\
\hline Ölçeğe Göre Artan Getiriler & İçsel Ölçek Ekonomileri \\
\hline Eksik Rekabet Piyasaları & Dixit-Stiglitz Modeli \\
\hline Ulaşım Maliyetleri & Buzdağı ulaşım maliyetleri \\
\hline Endüstri içi Ticaret & İleri- Geri bağlantılar \\
\hline Faktörlerin Hareketliliği & İşgücünün Hareketliliği: Ücret farklılıkları \\
\hline Kaynak: Head ve Mayer, 2003: 11 (Yazarların katkılarıyla geliştirilmiştir.) \\
\hline
\end{tabular}

Çeşitlik kavramı, esas olarak 1980'li yıllardan beri süre gelen talep yapısındaki değişimleri yansıtmaktadır. Talep yapısındaki değişimleri göz önünde bulunduran firmalar, ürün farklılaşması yoluyla daha geniş pazarlara erişmeye çalışmaktadırlar. Tüketiciler ise, taleplerini karşılayacak yerli ve yabancı daha geniş ürün yelpazesine kolay erişim olanağ1 olan bölgeleri tercih etmektedirler (Aries ve Grajeda, 2009:13). Çeşitlilik kavramı, modellere Krugman basit modelinde de olduğu gibi CES fonksiyonu aracılığı ile dahil edilmektedir.

Ölçeğe göre artan getiriler ve eksik rekabet piyasaları birlikte endüstriyel yığınlaşmaları tetikleyici rol oynamaktadır. Firma bazında içsel ölçek ekonomileri karlılığı arttırmakta ve dolayısıyla ülkenin çekiciliğinin artmasına neden olmaktadır. Dixit-Stiglitz Modeli, eksik rekabet piyasalarını Yeni Ekonomik Coğrafya Modellerine dahil ederek hem çeşitliliğin hem de ölçeğe göre artan getirilerin daha net bir biçimde ifade edilmesini sağlamaktadır.

Yeni Ekonomik Coğrafya Yaklaşımı'nın en önemli özelliğini ulaşım maliyetleri oluşturmaktadır. Yeni Ekonomik Coğrafya çerçevesinde ulaşım maliyetleri daha çok Samuelson (1952) tarafından tanımlanan ve herhangi bir malın bir parçasının nakil sırasına kaybolması anlamına gelen buzdağı ulaşım maliyetleri olarak modele dahil edilmektedir (Fujita ve Krugman, 2004: 143). Ulaşım maliyetleri olmadan coğrafyanın ekonomi üzerindeki 


\section{Ege Strategic Research Journal}

etkileri ifade edilememektedir (Bosker ve Garretsen, 2010: 485). Ulaşım maliyetlerinin düşük olması hem tedarikçilere hem de pazarlara daha kolay erişim olanağı sunduğu için faktörlerin hareketliliği aracılığıyla ülkenin çekiciliğini arttırmakta ve yığınlaşmaların görülmesine neden olmaktadır.

Eksik rekabet piyasaları ve ölçeğe göre artan getiriler söz konusu olduğunda, ülkenin girdi-çıktı bağlantı yapısının önemi artmaktadır. Bu kapsamda, eğer Yeni Ekonomik Coğrafya Yaklaşımı'ndan bahsediliyorsa, endüstri içi girdi-çıktı bağlantı yapısından da bahsetmek gerekmektedir. Çünkü bu yapı geri bağlantılar yoluyla piyasa büyüklüğünü, ileri bağlantılar yoluyla da maliyetleri etkilemektedir (Haaland ve vd, 1999: 12).

Yeni Ekonomik Coğrafya Yaklaşımı'nda faktörlerin hareketliliğgi, aslında işgücünün sektörler ve ülkeler arasında hareketli olduğunu ifade etmektedir. Yaklaşımın diğer özelliklerinin yanında, işgücünün hareketli olması modelin dinamik denge koşullarını sağlamasında en önemli etken olarak karşımıza çıkmaktadır. Firma bazında artan getirilerin ve ulaşım maliyetlerinin düzeyi, firmaların hangi ülkede üretim yapacakları kararını etkilemekte yani üretimin geçekleşeceği yerin belirlenmesini sağlamaktadır. Ancak, işgücünün ülkeler arasında hareketli olması, yığın ekonomilerinin ve endüstriyel kümelerin oluşumuna neden olmakta hatta yığın ekonomilerinin büyüklüğünü belirlemektedir (Brakman ve Garretsen, 2003:641). Bir başka deyişle, hareketli işgücü; yerleştiği ülkenin ve ayrıldığ1 ülkenin üretim yapısını ve ülkedeki üretimin mekansal dağılımını etkilemektedir (Fujita ve Thisse, 2009: 113). Bu kapsamda işgücünün yerleşim yeri kararları ülkenin ekonomik yapısını şekillendirdiği için oldukça önemlidir. Yeni Ekonomik Coğrafya Yaklaşımı'na göre işgücü yerleşim kararlarını, ülkeler arasındaki ücret farklılıklarını değerlendirerek vermektedir. Firmalar genişleyen pazarlar nedeniyle üretim artışı için işgücü taleplerini arttırmaktadırlar. Ücret artışları piyasaya ve tedarikçilere erişim kolaylığı ile finanse edilebildiği sürece 
işgücünü firmaya çekebilmek amacıyla kullanılmaktadır. Ancak, bu yaklaşım ücretlerin birbirine yakın olduğu ülkeler arasında işgücünün yerleşim yeri seçimlerini hangi unsurları göz önünde bulundurarak yaptığına açıklama getirememektedir. $\mathrm{Bu}$ aşamada karşımıza ekonomik etkilerin yanında sosyo-kültürel etkilerinde işgücünün yerleşim kararlarında etkili olduğunu vurgulayan Evrimci Ekonomik Coğrafya Yaklaşımı çıkmaktadır.

\section{Evrimci Ekonomik Coğrafya Yaklaşımı ve İşgücü Mobilitesi}

Öncülüğünü Martin ve Sunley (2006), Boschma ve Frenken (2006) gibi iktisatçıların yaptığ1 yaklaşım, Yeni Ekonomik Coğrafya Yaklaşımını reddetmemekte, ancak bazı eksiklikleri olduğunu belirtmektedir. Evrimci Ekonomik Coğrafya Yaklaşımı, ekonomik coğrafya yaklaşımlarında üçüncü nesil çalışmaların arasında kabul edilmektedir. Evrimci İktisadın temel prensipleri çerçevesinde firmaların, endüstrilerin, ağ yapılarının, şehirlerin ve bölgelerin gelişme aşamalarını hem mekansal bağlamda hem de tarihsel bağlamda incelemektedir. Evrimci Ekonomik Coğrafya Yaklaşımı iktisadi faaliyetlerin mekansal dağılımını tarihsel süreçte ele aldığı için ekonomik coğrafya teorilerine yeni bir bakış açısı kazandırmaktadır (Boschma ve Frenken, 2011:295-296). Bugünkü ekonomik koşulların yanında, tarihsel süreçte o coğrafyada yaşanan değişimlerin ve gelişmelerin mekansal dağılımı önemli ölçüde etkilediğini vurgulamaktadır.

Evrimci Ekonomik Coğrafya Yaklaşımı'nın temel özellikleri; rutinler, patika bağımlılığı, artan getiriler, şans ve seçimler olarak karşımıza çıkmaktadır. Bu yaklaşımda ayrıca, teknolojik gelişmeler, bilgi dışsallıkları ve yayılmaları da modele dahil edilerek dinamik ve çoklu dengeler elde edilmektedir (Garretsen ve Martin, 2010: 148). 
Ege Strategic Research Journal

Tablo 4:

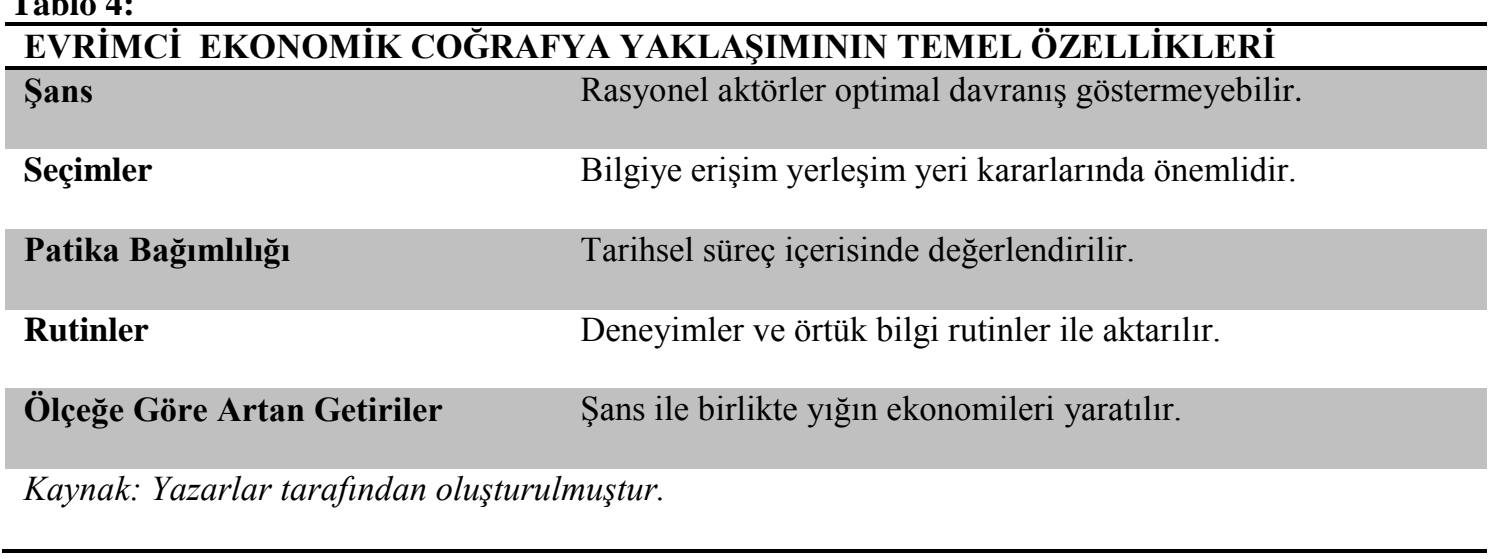

Evrimci Ekonomik Coğrafya Yaklaşımı yeni firmaların yerleşim yeri kararlarının doğru sonuçlar vermesini ekonomik etkenlerin yanında şans faktörüne dayandırarak açıklamaktadır. $\mathrm{Bu}$ yaklaşıma göre, firmalar optimal yerleşim yeri kararlarını verirlerken rasyonel davranış göstermeyebilmektedir. Bir başka ifade ile yerleşim yeri kararlarında firmaya özgü özellikler (firma sahibinin doğduğu şehirde firmayı kurması) ön plana çıkmakta ve şans eseri yerleşim yeri kararı seçimi optimal sonuç verebilmektedir (Boschma ve Lambooy, 1999: 413-414).

Evrimci Ekonomik Coğrafya Yaklaşımı'nda her ne kadar şans faktörü ön plana çıkarılsa da ekonomik aktörlerin seçimleri göz ardı edilmemektedir. Bu yaklaşıma göre, ekonomik aktörler; seçimlerini belirlerken mümkün olduğunca, bilgiye erişimin kolay olduğu yerleri tercih etmektedirler. Yani bir ülkenin yenilikçi kapasitesi seçimlere ve ölçeğe göre artan getirilere bağlı olarak belirlenmektedir.

Patika bağımlılığı, ekonomik coğrafya yaklaşımlarının temel konusu olan mekansal dağılıma zaman boyutunu eklemektedir. Evrimci Ekonomik Coğrafyacılara göre, ülkede geçmişte görülen ekonomik, sosyo-kültürel ve kurumsal gelişmeler ve değişimler, ülkenin bugünkü yapısını etkileyerek ortaya çıkan yı̆̆ın ekonomilerinin büyüklüğünü ve gelişim yönünü belirlemektedir. Kısacası, patika bağımlılı̆ğ geçmiş süreçlere bağlı kalmak olarak tanımlanmaktadır (Martin ve Sunley, 2006: 399). Patika bağımlılığı, bazı ülkelerin veya 
firmaların diğerlerine göre neden geri kaldığını da açıklamaktadır. Bu tarz ülkeler veya firmalar, geçmişte kullandıkları teknolojiye veya kurumsal yapılara katı bir şekilde bağlı oldukları için yeni gelişmelere kolay uyum sağlayamamakta veya uyum süreçleri daha uzun zaman almaktadır (Boschma ve Lambooy, 1999: 416).

Rutinler, hem firma hem de ülke gelişiminde oldukça önemlidir. Rutinler zaman içerisinde deneyim ve bilgi birikimi ile oluştuğu için firmaya özgüdür. Evrimci Ekonomik Coğrafya Yaklaşımın'da firmaların üretim ve karar süreçleri, firmanın kendine özgü organizasyonel rutinlerine bağlanmaktadır. Dolayısıyla, diğer firmalar tarafından kolaylıkla kopyalanamamaktadır. Firmaların organizasyonel ya da ürün bazındaki rutinleri, firmalar arasındaki gelişme düzeylerinin farklı olmasına yol açarak ülkenin gelişim düzeyini de etkilemektedir. Ancak, firmaların bölünmesi ve işgücünün mobilitesi aracılığıyla transfer edilebilmektedir (Frenken ve Boschma, 2007: 637). Bu açıdan bakıldığında rutinler bilgi ve deneyimlerin transferinde önemli bir etken olarak karşımıza çıkmaktadır.

Ölçeğe göre artan getiriler Yeni Ekonomik Coğrafya Yaklaşımda olduğu gibi Evrimci Ekonomik Coğrafya Yaklaşımında da yığın ekonomilerinin ve kümelenmelerin oluşumunda önemli etkiye sahiptir.

Ekonomik aktörler sınırlı rasyonelliğe sahip oldukları için formal modelleme ekonomik ve sosyal yaşam arasındaki doğal ilişkileri göz ardı etmektedir (Boschma ve Frenken, 2006: 280). Evrimci çerçevede ise, iktisadi faaliyetler sosyal ve kurumsal boyutlarıyla da incelenmektedir. İktisadi aktörler çevrelerini kendi ihtiyaçlarına uygun hale dönüştürürken, bir yandan da çevrenin kurumsal yapısını etkilemektedirler (Hassink ve Klaering, 2009: 5). Karar süreçleri, fayda maksimizisyonundan çok sınırlı rasyonellik ve rutin davranışlara dayandırılmaktadır (Boschma ve Frenken, 2006: 277). Dolayısıyla işgücünün hareketlilik kararları bu yaklaşıma göre sadece ekonomik değil, aynı zamanda göç edilen ve edilecek ülkenin sosyal ve kurumsal yapısına da bağlıdır. Evrimci Ekonomik Coğrafya bu özelliği ile 


\section{Ege Strategic Research Journal}

Yeni Ekonomik Coğrafya’nın eksik bıraktığı sosyal yapıyı da içererek işgücünün yerleşim yeri kararlarını etkileyen diğer faktörleri de göz önünde bulundurmanın gerekliliğini ortaya koymaktadır. Bu sayede ekonomik coğrafya modellerini günümüz koşullarına daha uygun hale getirmektedir.

\section{AB15 Ülkelerinde İşgücü Hareketliliğini Etkileyen Faktörlerin Analizi}

\subsection{Literatür İncelemesi}

Ekonomik coğrafya literatüründe işgücünün yerleşim yer kararlarını ampirik olarak inceleyen çok az sayıda çalışma bulunmaktadır. Bu kapsamda yapılan önemli çalışmalardan biri Brakman, Garretsen ve Schramm’ın (2002) Almanya 151 bölgesi üzerinde 1985 - 1995 zaman aralığında kesit veri kullanarak incelediği çalışma olarak karşımıza çıkmaktadır. Brakman vd. çalışmalarında Helpman-Hanson'ın geliştirdiği ücret yaklaşımını kullanarak Almanya'nın hem ücret yapısını hem de istihdam yapısının bölgesel dağılımını incelemişlerdir. Uyguladıkları modelin değişkenleri saat başı ücretler, ulaşım maliyetlerini belirtmek için iki bölge arasında araçla gidilen saat, bölgedeki yerleşim yerlerindeki konutların oda sayısı, istihdam, fiyatlar ve konut fiyatlarının göstergesi olarak arazi kiraları olarak belirlemişlerdir. Çalışmanın sonuçları, ekonomik coğrafya yaklaşımlarının ücretler ile ilgili önermelerini doğrulamaktadır. Bölgenin istihdam düzeyinin belirleyicilerinden biri bölgeler arası ücret farkları olarak bulunmuştur. Ayrıca, bölgedeki fiyatların ve arazi kiralarının istihdam dağılımında etkili olduğunu belirtmişlerdir.

Kemeny ve Storper (2012) çalışmalarında 1980 ve 2000 yılları arasında karşılaştırma yaparak Amerika'daki şehirlerarasındaki işgücü hareketliliğinin belirleyicilerini araştırmışlardır. Bu amaçla, işgücünün yerleşim yeri seçimi kararlarının ücretlerin, konut harcamalarının, iklimin, sağlık ve çevre koşullarının, suç oranının, toplu taşıma maliyetlerinin, okullaşma oranının, kültürel ve sanatsal aktivitelerin ve rekreasyonun bir fonksiyonu olduğunu ifade etmişlerdir. 
Kemeny ve Storper işgücü hareketliliğinin göstergesi olarak şehirlerin nüfus farklarını kullandıkları çalışmalarında, işgücünün yerleşim yeri seçimlerinin en çok ücretlerden ve iklimden etkilendiği sonucuna ulaşmışlardır.

Ezzeddine (2012) Avrupa Birliğinde özellikle 2008 ekonomik krizi sonrasında işsizliği azaltmada işgücünün hareketliliğinin rolünü incelediği çalışmasında işgücünün yerleşim yeri seçiminde etkili olan faktörleri ücret farkları, Gayrisafi Yurtiçi Hasıla farkları, kişi başına düşen Gayrisafi Yurtiçi Hasıla farkları, işsizlik oranları farkları, karşılıklı ticaret, mesafe ve ağyapı ilişkileri olarak tanımlamıştır. Analizinde çekim modelini kullanan Ezzeddine, ayrıca kukla değişken olarak modele ülkelerin sınır komşusu olup olmadığını ve ortak dil kullanıp kullanmadıklarını da eklemiştir. 1995-2008 yılları arasında GMM metodu uyguladığı çalışmasının sonuçları, ticaret liberalizasyonun işgücünün hareketliliğini desteklediğini göstermektedir. Ayrıca, işçilerin ücretlerin ve gayisafi yurtiçi hasılanın yüksek olduğu, ancak işsizliğin düşük olduğu ülkeleri tercih ettiğini bulmuşlardır. Kukla değişken olarak belirlenen ortak dil ve ortak sınır ise anlamlı sonuçlar vermemiş yani mekansal bağlamda bir ilişki belirlenememiştir.

Literatür incelendiğinde çalışmaların çoğunluğunun, işgücünün hareketliliğini sadece ücret farklılıkları ile ilişkilendirerek analiz ettiği belirlenmiştir. Kısacası, işgücünün yerleşim yeri seçimlerinde ekonomik tercihler göz önünde bulundururken, sosyo-kültürel tercihler göz ardı edilmiştir. Ancak böyle bir durum da işgücünün ücret farklılıklarının birbirine yakın olduğu ülkeler arasında nasıl seçim yaptığı açıklanamamaktadır. Çalışmanın izleyen bölümünde, işgücünün yerleşim yeri seçim kararlarında ekonomik faktörlerin yanı sıra sosyo-kültürel faktörlerin etkili olup olmadığı analiz edilerek literatürdeki bu soruna cevap bulunmaya çalışılmıştır. 


\section{Ege Strategic Research Journal}

\subsection{Veri, Yöntem ve Ampirik Sonuçlar}

\subsubsection{Veri ve Yöntem}

Çalışmanın bu bölümünde işgücünün yerleşim yeri kararlarını etkilen faktörler ekonomik coğrafya yaklaşımı çerçevesinde 2003-2010 yılları arasında Avrupa Birliği’ne üye 15 ülke örneği (Avusturya, Belçika, Danimarka, Finlandiya, Fransa, Almanya, Yunanistan, İrlanda, İtalya, Lüksemburg, Hollanda, Portekiz, İspanya, İsveç, İngiltere) üzerinden incelenmektedir. Literatürde yapılan çalışmalar incelendiğinde, genel olarak kesit veri analizlerinin yapıldığ görülmektedir. Bu çalışmada ise, işgücünün yerleşim yeri seçimi kararlarını hem ekonomik hem de sosyo-kültürel bağlamda etkileyen faktörler panel veri analizi kullanılarak incelenmektedir. Oluşturulan modelde işgücünün hareketliliğini etkileyen faktörler olarak ücretler, satın alma gücü paritesi, eğitime katılım düzeyi, suç oranları ve sosyal güvenlik harcamaları olarak belirlenmiştir.

$\log \left(\mathrm{N}_{1} / \mathrm{N}_{2}\right)_{\mathrm{t}}=\alpha_{1}+\alpha_{2} \log \left(\mathrm{W}_{1} / \mathrm{W}_{2}\right)_{\mathrm{t}-1}+\alpha_{3} \log \left(\mathrm{PP}_{1} / \mathrm{PP}_{2}\right)_{\mathrm{t}-1}+\alpha_{4}\left(\mathrm{EDUA}_{1} / \mathrm{EDUA}_{2}\right)_{\mathrm{t}-1}+$ $\alpha_{5} \log \left(\mathrm{CRIM}_{1} / \mathrm{CRIM}_{2}\right)_{\mathrm{t}-1}+\alpha_{6} \log \left(\mathrm{S}_{1} / \mathrm{S}_{2}\right)_{\mathrm{t}-1}+\alpha_{7} \log \left(\mathrm{N}_{1} / \mathrm{N}_{2}\right)_{\mathrm{t}-1}+\mathrm{u}_{\mathrm{it}}$

İşgücünün hareketlilik kararlarını ancak bir dönem önceki faktörleri göz önünde bulundurarak vereceğini düşünerek açıklayıcı değişkenlerin tümünde bir yıl önceki gecikmeli değerleri kullanılmıştır. Bağımlı değişkenin gecikmeli halinin de modelde bağımsız değişken olarak bulunması nedeniyle analiz, dinamik panel veri analizi haline gelmiştir. Ayrıca modelde kullanılan tüm değişkenlerin ülkelerarası farkları kullanılmıştır. 1, 1. ülkeyi, 2, 2. ülkeyi ifade etmektedir. Örneğin, 1. Ülke Almanya ise, tüm değişkenler için diğer 14 ülkeye ait aynı değişken ile arasındaki fark sırasıyla hesaplanmıştır. Bu sayede her yıl için 105 kesit veri elde edilmiştir. Bunun nedeni, ekonomik coğrafya yaklaşımlarında işgücünün yerleşim yeri kararlarının ülkeler arası ekonomik ve sosyo-kültürel farklardan etkilenmesidir. Ancak, değişkenlerin ülkelerarası farkları negatif sonuçları da beraberinde getirmekte ve logaritmik 
forma çevrilmesini engellemektedir. Bu nedenle Ezzeddine’nin (2012) izlediği yöntem takip edilerek değişkenlerin logaritmik farkları alınmış ve modele $\mathrm{N}_{1} / \mathrm{N}_{2}$ şeklinde yansıtılmıştır.

Tablo 5 :

\section{DEĞİSTENLER VE VERİ KAYNAKLARI}

\begin{tabular}{lll}
\hline$\underline{\text { Değisken }}$ & $\underline{\text { Açıklama }}$ & $\underline{\text { Kaynak }}$ \\
\hline N: Nüfus & 15-64 yaş arası çalışabilir nüfus & ILO \\
W: Ücret & Yıllık ücretler (euro) & Eurostat \\
PP: Satın alma gücü & Satın alma Gücü Paritesi & Eurostat \\
EDUA: Eğitim & $15-24$ yaş arası eğitime katılan nüfus & Eurostat \\
CRIM: Suç Oranı & Polise bildirilen suç oranı & Eurostat \\
S: Sosyal Güvenlik Harcamaları Sosyal Güvenlik Harcamaları & Eurostat \\
\hline Kaynak: Yazarlar tarafindan oluş̧urulmuşstur. & \\
\hline
\end{tabular}

Bağımlı değişken olarak işgücünün hareketliliğini temsil edebilmek için AB15 ülkelerindeki 15-64 yaş aralığındaki çalışabilir nüfusun farkları kullanılmıştır. Bağımlı değişken olarak ülkelerin aldığı göçlerin kullanılmamasının nedeni; göç edenlerin tamamının işgücüne katılan nüfus olmamasıdır. Bazı veri kaynaklarında işgücünün göç verileri bulunmaktadır, ancak bu verilerin zaman aralığı oldukça kısa ve düzensiz olduğu için çalışmada kullanılmamıştır. Aktif nüfusun bağımlı değişken olarak kullanılması, işgücüne katılabilecek düzeyde olan hanehalklarının sadece göç eğilimlerini değil o ülkeyi tercih etme isteklerini de ifade etmektedir. Ayrıca modelin dinamik hale gelebilmesi hem de bir önceki dönemde o ülkeler arasındaki çalışabilir nüfusun bugünkü çalışabilir nüfus farkına etkisini görebilmek adına bağımlı değişkenin 1 gecikmeli hali bağımsız değişken olarak modele eklenmiştir.

Modelin ikinci açıklayıcı değişkeni, Yeni Ekonomik Coğrafya Yaklaşımına göre işgücünün hareketliliğini etkileyen tek faktör olan ülkeler arası ücret farklılıklarıdır. Nüfusu fazla olan ülkelerin piyasaya erişim imkanları daha fazladır ve işgücünü ülkeye çekmek için daha yüksek ücretler sunarak ülkenin çekiciliğini arttırmaya çalışmaktadırlar (Venables, 2005: 6). 


\section{Ege Strategic Research Journal}

İşgücü de yerleşim yeri seçimini yaparken ücretlerin yüksek olduğu ülkeleri tercih etmektedir. Dolayısıyla, ülkeler arasındaki ücret farklarının işgücünün hareketliliğini pozitif etkilemesi beklenmektedir.

Üçüncü değişken, yaşam maliyetini yansıtması için satın alma gücünün ülkeler arası farkıdır. İşçiler yerleşim yeri kararlarında o ülkede yaşamanın maliyetlerini de göz önünde bulundurarak, satın alma gücünün yüksek olduğu ülkeleri tercih edeceklerdir. Bu nedenle ülkeler arası satın alma gücü farklarının işgücünün hareketliliğini pozitif etkileyeceği düşünülmektedir.

Ülkelerin eğitim, güvenlik ve sosyal olanakları, çalışabilir nüfusun hareketliliğinin diğer nedenleri olarak karşımıza çıkmaktadır. Bu olanaklarının yüksek olması o ülkenin yaşam kalitesinin de yüksek olduğunu göstermektedir. İşgücü özellikle ücret ve fiyat düzeyleri birbirine yakın olan ülkeler arasında seçim yaparken ülkenin sosyal düzeyini göz önünde bulundurmaktadır. Bu etkileri analiz etmek amacıyla ülkeler arası eğitim düzeyi farklılıklarının göstergesi olarak ülkelerarası eğitime katılan nüfusun farklılıkları, güvenlik koşullarının göstergesi olarak ülkelerdeki polise bildirilen suç sayılarının farkları modele dahil edilmiştir. Modelin son değişkeni olarak ülkelerdeki sosyal güvenlik harcamalarının farkları kullanılmıştır. Bu değişkenlerden eğitim ve sosyal güvenlik harcamalarının ülkeler arasındaki çalışabilir nüfus farklarına pozitif etki yapmaları, suç oranları farklarının ise negatif etki yapmaları beklenmektedir.

\subsubsection{Ampirik Sonuçlar}

AB15 ülkeleri için 2003-2010 zaman aralığında öncelikle En Küçük Kareler yöntemi ile panel veri analizi yapılmıştır. Öncelikle tüm seriler 1. Nesil birim kök testlerine tabi tutulmuşlardır. Tablo 6 da görüldüğü üzere seriler düzeyde birim kök içermekte ve birinci farkları alındığında 
birim kök etkisinden kurtulmaktadırlar. $\mathrm{Bu}$ nedenle serilerin birinci farkları alınarak çalışmaya devam edilmiştir.

Tablo 6 :

\begin{tabular}{|c|c|c|c|c|}
\hline \multicolumn{5}{|c|}{ BİRİM KÖK TESTİ SONUÇLARI } \\
\hline \multirow[b]{2}{*}{ Değişkenler } & \multicolumn{2}{|l|}{ DÜZEY } & \multicolumn{2}{|l|}{ BİRINCİ FARK } \\
\hline & $\begin{array}{l}\text { Im, Pesaran and } \\
\text { Shin W-stat }\end{array}$ & $\begin{array}{l}\text { PP- Fisher } \\
\text { Chi-square }\end{array}$ & $\begin{array}{l}\text { Im, Pesaran and } \\
\text { Shin W-stat }\end{array}$ & $\begin{array}{l}\text { PP - Fisher } \\
\text { Chi-square }\end{array}$ \\
\hline $\log \left(\mathbf{N}_{1} / \mathbf{N}_{2}\right)$ & 1.0000 & 0.5306 & 0.0000 & 0.0000 \\
\hline $\log \left(\mathbf{W}_{1} / \mathbf{W}_{2}\right)_{t-1}$ & 0.9931 & 1.0000 & 0.0000 & 0.0000 \\
\hline $\log \left(\mathbf{P}_{1} / \mathbf{P}_{2}\right)_{t-1}$ & 0.9863 & 1.0000 & 0.0000 & 0.0000 \\
\hline $\log \left(\mathrm{EDUA}_{1} / \mathrm{EDUA}_{2}\right)_{\mathrm{t}-1}$ & 0.8243 & 0.0000 & 0.0000 & 0.0000 \\
\hline $\log \left(\mathrm{CRIM}_{1} / \mathrm{CRIM}_{2}\right)_{\mathrm{t}-1}$ & 0.9967 & 0.9977 & 0.0000 & 0.0000 \\
\hline $\log \left(\mathbf{S}_{1} / \mathbf{S}_{2}\right)_{t-1}$ & 0.9989 & 0.9991 & 0.0011 & 0.0000 \\
\hline Tablodaki değerler p ol & J̆ & ektedir & & \\
\hline
\end{tabular}

Birinci farkları alınmış serilere panel veride en küçük kareler yöntemi uygulandığında elde edilen sonuçlar tablo 7'de görülmektedir. 
Ege Strategic Research Journal

Tablo 7 :

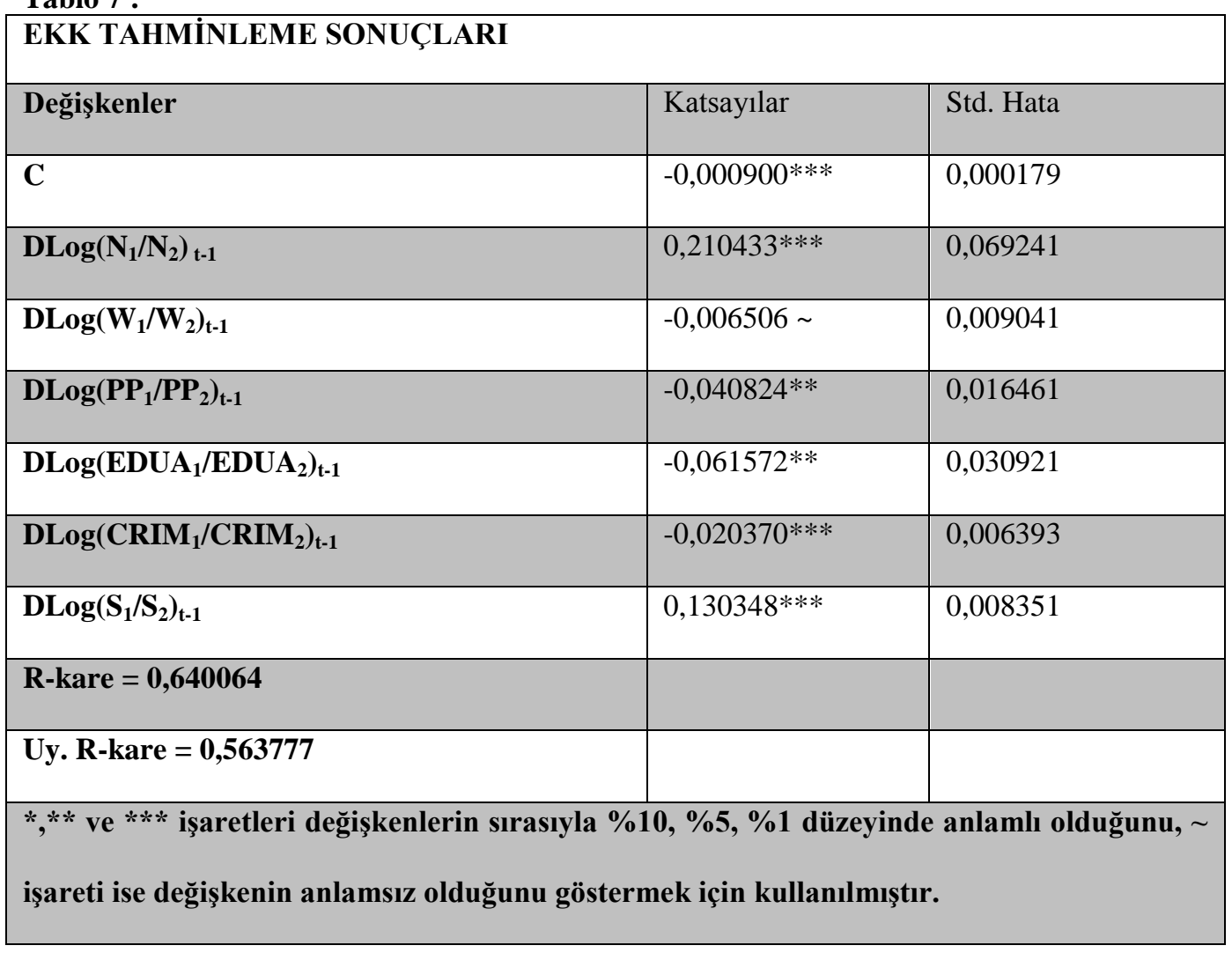

Tahminleme sonuçları incelendiğinde, ülkeler arası çalışabilir nüfus farklarının beklendiği gibi pozitif olduğu görülmektedir. Ülkeler arası ücret farklılıkları ise, beklentilerin aksine anlamsız çıkmıştır. Bir başka ifade ile, ücret farklarının işgücünün yerleşim yeri tercihleri üzerindeki etkisi anlamsızdır. Oysa, Yeni Ekonomik Coğrafya Yaklaşımına göre işgücünün yerleşim yeri kararları ülkeler arası ücret farklılıklarına bağlıydı. Modelde satın alma gücü paritesinin, eğitimin, suç oranlarının işgücünün yerleşim yeri seçimlerine etkisi anlamlı olsa da beklentilerin aksine sonuçlandığı görülmektedir.

Görüldüğü üzere En Küçük Kareler yöntemi kullanılarak elde edilen model sonuçları iktisadi olarak anlamlı değildir. Çünkü bu tarz bir modeli En Küçük Kareler Yöntemi kullanarak analiz etmek başta otokorelasyon ve içsellik olmak üzere pek çok sorunu da beraberinde getirebilmektedir. Dolayısıyla, En Küçük Kareler Yöntemi ile elde edilen tahmin sonuçlarının 
sapmalı olabileceği göz önünde bulundurulmalıdır. Bu nedenle analize tüm bu sorunları çözen Arellano-Bond fark Genelleştirilmiş Momentler Metodu kullanılarak devam edilecektir.

GMM uygulamasında araç değişken olarak bağımlı değişkenin gecikmeli hali kullanılmıştır. Tüm kontrol testleri uygulanmış ve modelde bir sorun ile karşılaşılmamıştır. Tablo 8 de verilen sonuçlar incelendiğinde, beklendiği gibi ülkeler arasındaki çalışabilir nüfus farklarının beklentilerin aksine negatif olduğu görülmektedir. Bir başka deyişle, ülkenin bir önceki dönemki çalışabilir nüfus çekiciliği bir sonraki dönemi etkilememektedir.

Tablo 8 :

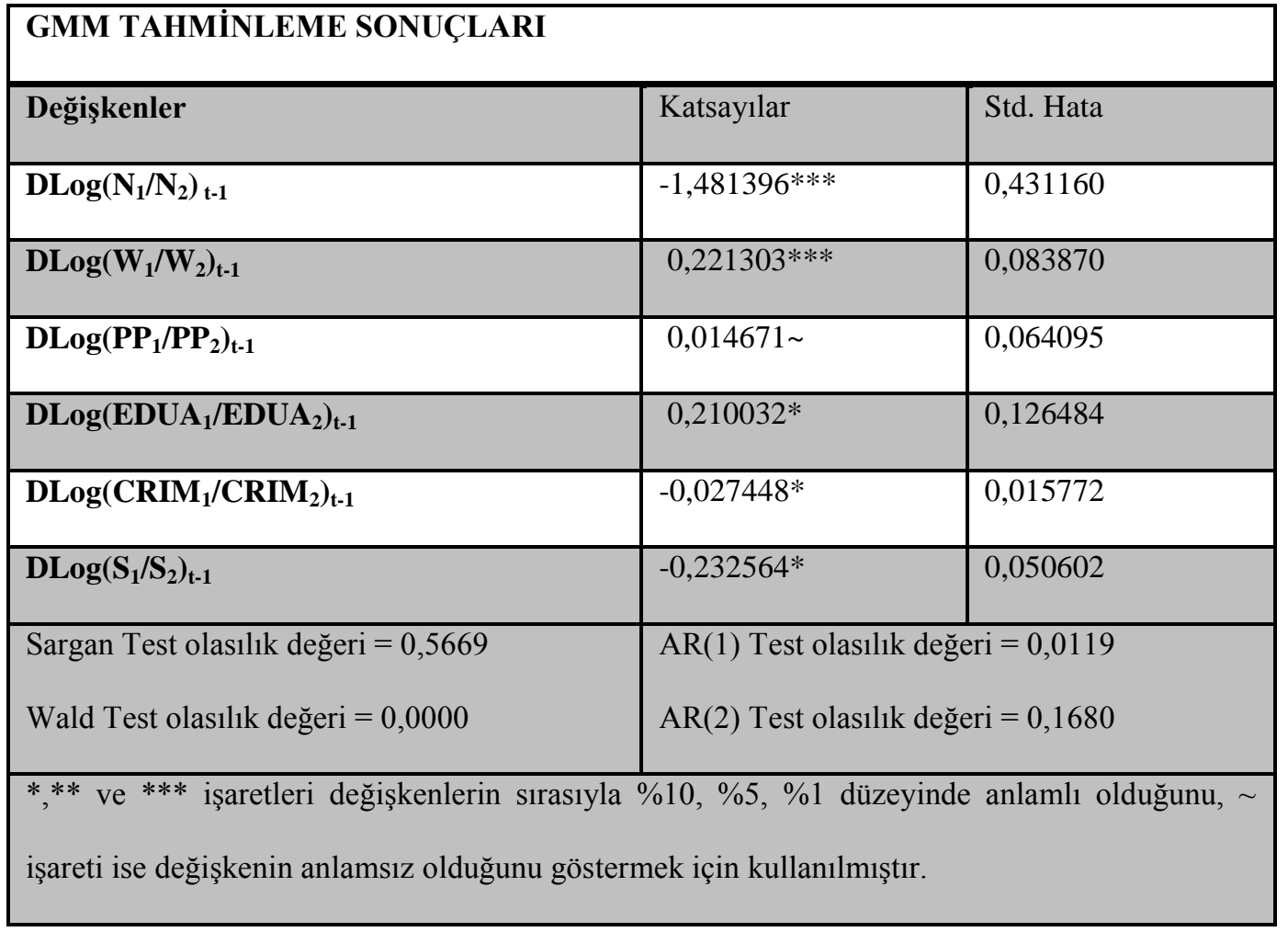

Yeni Ekonomik Coğrafya Yaklaşımı'nın işgücünün yerleşim yeri kararlarının belirleyicisi olduğunu vurguladığı ülkeler arası ücret farklılıklarının beklendiği gibi anlamlı ve pozitif olduğu gözlemlenmektedir. Bunun anlamı ise, ülkeler arası ücret farklılıkları arttıkça, işgücü ücretlerin yüksek olduğu ülkeleri tercih etmektedir.

Ülkeler arası fiyat farklılıkları yansıtmak için kullandığımız satın alma gücü farklılıkları yerleşim yeri seçimi için bir başka önemli unsur olarak karşımıza çıkmaktadır. Hareketlilik 


\section{Ege Strategic Research Journal}

kararları verilirken yerleşilecek ülkenin yaşam maliyetleri göz önünde bulundurulmaktadır. Bu bağlamda fiyatların düşük olduğu ülkeler tercih nedenidir. Ancak, elde edilen sonuçlar bu değişkenin anlamsız olduğunu ifade etmektedir. AB 15 ülkelerinin ekonomik verilerini göz önünde bulundurduğumuzda bu ülkelerin satın alma güçlerinin aslında birbirinden çok farklı olmadığını söyleyebiliriz.

15-24 yaş eğitime katılan nüfus farkları değişkenini incelediğimizde, bu değişkenin \%5 anlamlılık düzeyine göre anlamsız ancak \%10 anlamlılık düzeyine göre anlamlı ve pozitif olduğu görülmektedir. İşgücü yerleşim yeri kararını verirken yerleşeceği ülkenin eğitim düzeyini de dikkate almaktadır.

Polise bildirilen suç sayısı farkları değişkeni de eğitim değişkeninde olduğu gibi değişkenin $\% 5$ anlamlılık düzeyine göre anlamsız ancak \%10 anlamlılık düzeyine göre anlamlıdır. Beklendiği gibi ülkeler arasında polise bildirilen suç sayısı farklılıkları arttıkça, işgücünün yerleşim seçimi kararı negatif etkilenmektedir. Bir başka ifade ile işgücü yerleşim yeri kararını verirken, suç oranlarının düşük olduğu ülkeleri tercih etmektedir.

Son olarak ülkeler arası sosyal güvenlik harcamaları farklarını ifade eden değişkene ait sonuçlar incelendiğinde, sonuçların anlamlı ancak etkinin negatif olduğu ortaya çıkmaktadır. Oysaki beklentiler sosyal güvenlik harcamalarının fazla olduğu ülkelerin tercih edileceği yönündeydi. Sonucun negatif olmasının nedeninin sosyal güvenlik harcamalarının finansman şeklinden kaynaklandığı düşünülmektir. Pek çok AB ülkesinde (Danimarka, İrlanda ve İngiltere hariç) işçi ve işverenlerin ödediği primlerin devletin payından daha fazla olduğu Tablo 9 da da gösterilmektedir. İşçilerin yerleşim yeri kararını verirken eğer kayıtlı çalışacaklarsa, ödeyecekleri sosyal güvenlik paylarını da göz önünde bulundurmaktadır. 
Tablo : 9

\begin{tabular}{|c|c|c|c|c|c|}
\hline \multicolumn{6}{|c|}{ AB 15 SOSYAL GÜVENLİK KATKI PAYLARI -2005- } \\
\hline Ülkeler & $\begin{array}{l}\text { Hükümetin } \\
\text { Payı }\end{array}$ & $\begin{array}{l}\text { Sigortalı+İ̧sveren } \\
\text { payı }\end{array}$ & İşverenler & $\begin{array}{l}\text { İşçiler-kendi } \\
\text { hesabına } \\
\text { çalışanlar }\end{array}$ & Diğer \\
\hline Avusturya & 33 & 65 & 38 & 27 & 2 \\
\hline Belçika & 25 & 73 & 51 & 22 & 2 \\
\hline Danimarka & 63 & 29 & 10 & 19 & 8 \\
\hline Finlandiya & 44 & 50 & 39 & 11 & 6 \\
\hline Fransa & 31 & 66 & 45 & 21 & 4 \\
\hline Almanya & 36 & 63 & 35 & 28 & 2 \\
\hline Yunanistan & 31 & 58 & 36 & 23 & 11 \\
\hline İrlanda & 54 & 40 & 25 & 15 & 6 \\
\hline İtalya & 41 & 57 & 42 & 15 & 2 \\
\hline Lüksemburg & 45 & 51 & 27 & 24 & 3 \\
\hline Hollanda & 20 & 68 & 33 & 34 & 12 \\
\hline Portekiz & 42 & 48 & 32 & 16 & 10 \\
\hline İspanya & 33 & 65 & 49 & 16 & 2 \\
\hline İsveç & 48 & 50 & 41 & 9 & 2 \\
\hline İngiltere & 51 & 48 & 32 & 16 & 2 \\
\hline Kaynak: Eur & & & & & \\
\hline
\end{tabular}

\section{Sonuç ve Değerlendirme}

İşgücünün ülkeler arasında hareketliliği yığın ekonomilerin oluşmasını sağlayarak ülkelerin üretim yapısını ve üretimin mekansal dağılımını etkilemektedir. Kısacası, işgücünün kararları ülkelerin gelişme yönünü ve gelişmişlik düzeyini belirlemektedir. Dolayısıyla, ekonomik coğrafya modellerinde dinamik dengelerin sağlanmasının önemli bir aracı olarak karşımıza çıkmaktadır. Çalışma çerçevesinde ele alınan Yeni Ekonomik Coğrafya Yaklaşımı işgücünün 


\section{Ege Strategic Research Journal}

yerleşim yeri kararlarını sadece ülkeler arası ücret farklılıklarına bağlamaktadır. Bu durum yaklaşımın eleştiri aldığı noktaların başında gelmektedir. Çünkü ülkeler arası ücret farklılıklarının birbirine yakın olduğu ülkeler arasında yerleşim yeri seçimlerini etkileyen faktörleri belirleyememektedir. Bu kapsamda, üçüncü nesil ekonomik coğrafya yaklaşımları arasında da sayılan Evrimci Ekonomik Coğrafya Yaklaşımı yerleşim yeri seçimlerinde sosyokültürel faktörlerin de etkili olduğunu vurgulayarak yeni bir bakış açısı kazandırmaktadır.

Model sonuçları genel anlamda literatür ile aynı doğrultuda sonuçlar vermektedir. Buna ek olarak, Avrupa Komisyonu'nun 2010 yılında yayınladığı ve Eurobarometre “Geographical and Labor Market Mobility” Avrupa Birliği ülkelerinde işgücünün yerleşim yeri kararlarını inceleyen anket sonuçlarını değerlendirmektedir. Bu anket sonuçlarına göre, analize konu olan AB15 ülkelerinde yaşayan işgücü yerleşim yeri kararını verirken, öncelikle benzer kültür şartlarını ve daha fazla ücret elde etmeyi göz önünde bulundurmaktadır. Ayrıca, AB15 ülkelerinde yaşayan işgücünün aynı zamanda daha eğlenceli yaşam koşullarını, daha iyi eğitim almayı ve daha güvenli ortamı tercih ettiği görülmektedir. Anket sonuçları çalışmanın sonuçlarını destekler niteliktedir.

Ülkeler arasındaki ücret farklılıkları işgücünün yerleşim yeri tercihlerini pozitif yönde etkilemektedir. Yeni Ekonomik Coğrafya yaklaşımı nüfusun yoğun olduğu yani pazara erişim imkanlarının daha fazla olduğu ülkelerde üretim artışı sağlayabilmek için yüksek ücretler aracılığıyla işgücünün tercihlerini etkilediğini savunmaktadır. Model sonuçları da bu tezi doğrulamakta ve işgücünün seçimlerini yaparken ücretlerin daha yüksek olduğu ülkeleri tercih ettiğini göstermektedir.

Yaşam maliyetleri ülkelerin işgücünü çekim koşullarını etkilemektedir. Bu kapsamda modele dahil edilen satın alma gücü arasındaki farklılıklar değişkeni, AB 15 ülkelerinde birbirine yakın olması nedeniyle anlamsız çıkmaktadır. 
Modelde ayrıca ülkeler arası eğitim ve güvenlik olanakları da işgücü hareketliliğini etkileyen faktörler olarak incelenmiştir. İşgücü ülkeler arasında hareket ederken yaşam kalitesini ve koşullarını da dikkate almaktadır. Evrimci Ekonomik Coğrafya Yaklaşımında seçimler varsayımı oldukça önemlidir. İşgücü seçimlerini yaparken bilgiye erişim imkanlarının yüksek olduğu ülkeleri tercih ettiğini belirtmektedir. Modelin sonuçları da bu durumu doğrular niteliktedir.

Son olarak sosyal güvenlik harcamaları farklarını incelediğimizde beklentilerimizin aksi yönünde bir sonuç çıkmış ve bunun nedeninin sosyal güvenlik harcamalarında işçi ve işverenin ödediği katkı paylarının devletin ödediği paydan daha yüksek olması olduğu düşünülmektedir.

Tüm bu gelişmeler 1şı̆̆ında, ekonomik coğrafya yaklaşımlarında çerçevesinde yapılan analiz AB15 ülkelerinde işgücünün hareketliliğini etkileyen faktörleri net bir şekilde ortaya koymaktadır. Farklı veriler elde edildikçe ve serilerin yıl aralığı uzatıldıkça analiz kapsamı daha da geliştirilebilir hale gelecektir.

\section{Kaynakça}

Arias, A ve M. Grajeda. (2009). "Spatial Implications of International Trade Under The New Economic Geography Approach” MPRA Paper No: 18076.

Brakman, S. , H. Garretsen ve M. Schramm. (2002). "The Spatial Distribution of Wages and Employment: Testing the Helpman-Hanson Model for Germany”. University of Nijmegen.

Brakman, S ve H. Garretsen. (2003). "Rethinking the "New" Geographical Economics" Journal of Regional Studies, vol 37 no: 6/7.

Boschma, R ve J. Lambooy. (1999). "Evolutionary Economics and Economic Geography". Journal of Evolutionary Economics. Vol 9. ss 411-429.

Boschma, R ve K. Frenken. (2006). "Why is Economic Geography not an Evolutionary Science? Towards an Evolutionary Economic Geography". Journal of Economic Geography, 6. ss 273-302.

Boschma, R ve K. Frenken. (2011). "The Emerging Emprics of Evolutionary Economic Geography”. Jounal of Economic Geography. Vol 11. ss 295-307. 
Ege Strategic Research Journal

Bosker, M ve H. Garretsen. (2010). "Trade Costs in Empirical New Economic Geography”. Papers in Regonal Science. Vol 89, Issue 3. ss 485-511.

Dixit, A ve J. Stiglitz. (1977). "Monopolistic Competition and Optimum Product Diversity". American Economic Review, vol 67, No: 3.

Eurobarometer. 2010. "Geographical and Labor Market Mobility" http://ec.europa.eu/public_opinion/archives/ebs/ebs_337_en.pdf erişim tarihi 04.04.2013.

Ezzeddine, O. (2012). "The Role of Labour Mobility in Reducing Unemployment in the European Union”. University of Montesquieu Bordeaux IV.

Fujita, M. (1993). "Monopolistic Competititon and Urban Systems". European Economic Review, Elsevier, vol 37. ss 308-315.

Fujita, M. Ve P. Krugman. (2004). "The New Economic Geography: Past, Present and Future". Papers in Regional Science, 83.

Fujita, M ve J.F. Thisse. (2009). "New Economic Geography: An Appraisal on the Occasion of Paul Krugman's 2008 Nobel Prize in Economic Sciences". Regional Science and Urban Economics, Elsevier, Vol 39. ss 109-119.

Frenken, K ve R. Boschma. (2007). “A Theoretical Framework for Evolutionary Economic Geography: Industrial Dynamics and Urban Growth as a Branching Process". Jounal of Economic Geography. Vol 7. ss 635-647.

Garretsen, H ve R. Martin. (2010). "Rethinking (New) Economic Geography Models: Taking Geography and History More Seriously”. Spatial Economic Analysis, 5. ss 127-160.

Haaland, J. , H. Kind, K. MidelfartKnarvik ve J. Torstensson. (1999). "What Determines The Economic Geography of Europe”. CEPR Discussion Paper, No: 2072.

Hassink, R ve C. Klaerding. (2009). "Relational and Evolutionary Economic Geography: Competing or Complementary Paradigms?". Utrecht University Papers in Evolutionary Economic Geography.

Head, K ve T. Mayer. (2003). "The Emprics of Agglomeration and Trade”. CEPII, No: 200315 October.

Kemeny, T ve M. Stolper. (2012). "The Sources of Regional Development: Wages, Housing and Amenity Gaps Across American Cities". Journal of Regional Science. Vol 52. No 1. ss 85-108.

Krugman, Paul. (1991). "Increasing Returns and Economic Geography". The Journal of Political Economy, Vol 99, No: 3.

Krugman, P. (1998). "Whats New About Economic Geography". Oxford Review of Economic Policy, Vol 14. No: 2. ss 7-17. 
Krugman, P. (1998). "The Role of Geography in Development". Annual World Bank Conference on Development Economics, Washington.

Martin, R ve P. Sunley. (2006). "Path Dependence and Regional Economic Evolution" Journal of Economic Geography. Vol 6. ss 395-437.

Martin, R. (2010). "The New Economic Geography "Credible Models of The Economic Landscape?"' Sage Handbook of Economic Geography. ss 53-73.

Puga, D. (1999). “The rise and Fall of Regional Inequalities". European Economic Review 43. ss 303-334.

Redding, S. (2009). “The Emprics of New Economic Geography” CEPR.

Samuelson, P. (1952). "The Transfer Problem and Transport Costs: The Terms of Trade When Impediments are Absent”. Economic Journal. Vol 62. ss 278-304.

Schmutzler, A. (1999). "The New Economic Geography”. Journal of Economic Surveys. Vol 13. No: 4.

Venables, A. (1996). "Equilibrium Locations of Vertically Linked Industries". International Economic Review, Vol. 37. No 2. ss 341-359.

Venables, A. (1998). “The Assesments: Trade and Location". Oxford Review of Economic Policy. 14.

Venables, A. (2005). "Economic Geography: Spatial Interactions in the World Economy". CEPR. 